\title{
A conceptual framework of the relationship between total quality management, corporate social responsibility, innovation capability, and financial performance
}

\author{
Younès El Manzani* \\ Department of Management, \\ FSJES Marrakesh, \\ Cadi Ayyad University, \\ BP: 2380, Daoudiate, Marrakesh, Morocco \\ and \\ Department of Management, \\ IAE School of Management, \\ Jean Moulin Lyon 3 University, \\ 6 Cours Albert Thomas, 69008 Lyon, France \\ Email: younes.elmanzani@gmail.com \\ *Corresponding author
}

\section{Mohamed Larbi Sidmou}

Department of Management, FSJES Marrakesh, Cadi Ayyad University, BP: 2380, Daoudiate, Marrakesh, Morocco Email:ml.sidmou@uca.ac.ma

\author{
Jean-Jack Cegarra \\ Department of Management, \\ IAE School of Management, \\ Jean Moulin Lyon 3 University, \\ 6 Cours Albert Thomas, 69008 Lyon, France \\ Email: jean-jack.cegarra@univ-lyon3.fr
}

\begin{abstract}
Total quality management, corporate social responsibility, and innovation are considered as strategic orientations allowing the achievement of a sustainable competitive advantage. However, there is a gap in the literature regarding the study of the links between these three concepts in a single analysis, the majority of researchers do not gather the study of these three concepts at once, as they do not as well link them to the financial performance. The main purpose of this conceptual paper is to examine the relationship between quality, innovation, corporate social responsibility and financial performance. We are aiming to build a conceptual framework with a particular emphasis on the role that may be played by TQM practices in the development of the bidirectional link between corporate social responsibility-innovation capability, and its impact on the improvement of the firm's financial performance.
\end{abstract}


Keywords: total quality management; TQM; corporate social responsibility; CSR; innovation capability; financial performance.

Reference to this paper should be made as follows: El Manzani, Y., Sidmou, M.L. and Cegarra, J-J. (2017) 'A conceptual framework of the relationship between total quality management, corporate social responsibility, innovation capability, and financial performance', Int. J. Quality and Innovation, Vol. 3, Nos. 2/3/4, pp.188-208.

\section{Introduction}

Corporate social responsibility (CSR), total quality management (TQM), and innovation are considered as strategic orientations allowing the achievement of a sustained competitive advantage. The current importance of organisations in the society is justified by the multiplicity of ecological, social and economic challenges. Firms are increasingly constrained to behave in a socially responsible manner in order to create value for all stakeholders. Therefore, CSR is thought to be an efficient, proactive strategy for achieving better financial performance, and an active source of competitive advantage. Moreover, TQM is recognised as a management philosophy widely adopted by managers, while focusing on the continuous improvement of the organisation's processes, meeting customer needs, it also allows the firm to increase its profitability and achieve a higher level of excellence. Likewise, innovation is also a key element to gain in terms of performance and competitiveness; firms are necessarily required to develop their innovation capability to maintain their position in highly unpredictable markets characterised by extremely rapid technological development. 
The relationship between CSR and financial performance was largely studied in the literature, but the obtained results remain controversial and paradoxical (Cochran and Wood, 1984; Nollet et al., 2016; Waworuntu et al., 2014), and there is no consensus in the debate on this relationship (Hull and Rothenberg, 2008). Therefore, McWilliams and Siegel (2000) claim that it is important to consider more complex possibilities when examining the CSR-financial performance relationship, they add that innovation should thus be included when modelling this relationship. Besides being a strong predictor of financial performance, innovation capability may complement the CSR impact on financial performance, because innovation and CSR are considered as two major modern topics (Labelle, 2008). They can and should be reciprocally reinforcing, for the reason that the future economy is based on their complementarity. Concerning this complementarity, there is little work on their interactions (e.g., MacGregor and Fontrodona, 2008), and their organisational consequences in terms of performance. In addition, we know little about how a firm can establish and manage the interaction between CSR and innovation capability to enhance financial performance. Gallego-Álvarez et al. (2011) showed that the bidirectional relationship between CSR and innovation is negative. In this sense, TQM can act as a facilitator and optimiser of this interaction since the implementation of TQM practices produce organisational changes that enable the incorporation of CSR and the development of innovation capability (McAdam and Leonard, 2003; Perdomo-Ortiz et al., 2006; Zink, 2007). In one hand, quality management practices facilitate the development of environmental management and activities that are socially responsible (Curkovic, 2003; Withanachchi et al., 2007). On the other hand, TQM practices create a fertile and favourable environment for developing innovation capability (Martínez-Costa and Martínez-Lorente, 2008; Prajogo and Sohal, 2001). In spite of the interrelationships between TQM, CSR, and innovation, there is a literature gap regarding the study of the links between these three concepts in a single analysis. To the best of our knowledge, there is no study integrating them at once, as well as linking them to the financial performance. Furthermore, the few empirical studies that examined their separate partial integration have produced some ambiguous and less conclusive results.

Thereof, this paper seeks to conceptualise the relationship between quality, innovation, CSR and financial performance. Relying on prior conceptual and empirical studies in these three areas, we are aiming to build a conceptual framework with special emphasis on the role that may be played by TQM practices in the development of the bidirectional link CSR-innovation capability, and its impact on the improvement of the firm's financial performance. The research question formulated for our study is the following: 'To which extent the bidirectional link CSR-innovation capability can be supported by TQM in order to achieve a superior financial performance?'. We are also aiming to clarify these two sub-questions: How can TQM catalyse innovation capability and CSR, and serve as a support platform for their bidirectional link? Will the bidirectional relationship CSR-innovation capability backed by TQM has a positive impact on the financial performance of the firm?

After this introduction, our paper is structured as follows: the first section is a brief discussion of the key concepts, namely TQM, CSR, innovation capability and financial performance. The second section is devoted to the theoretical exploration of the links between these concepts and their impact on the financial performance of the firm in order to subsequently build a conceptual framework. The conclusion will provide an overview 
of the theoretical and managerial contribution of our research, and of the methodological aspects and anticipated limitations.

\section{Literature review}

\subsection{Total quality management}

TQM is a management concept developed by Deming, Juran, Ishikawa, Feigenbaum, Taguchi and Crosby, widely recognised as a management philosophy which has attracted the interest of a wide public, including academics, scientists, practitioners, engineers and many others who have proposed a variety of definitions (Mahmud and Hilmi, 2014). Flynn et al. (1994, p.342) define TQM as "an integrated approach to achieving and sustaining high quality output, focusing on the maintenance and continuous improvement of processes and defect prevention, in order to meet or exceed customer expectations". Porter and Tanner (2001) see it as "business process focusing on improving organizational effectiveness, efficiency and responsiveness to customer needs by actively involving people in process improvement activities" (Rungtusanatham et al., 2005). ISO 9001:2000 considers TQM as the management style of an organisation focusing primarily on quality and the participation of all the members, it aims for a long term success by providing customer satisfaction and benefits for the organisation's members and society (Dhiaf, 2007). According to Sadikoglu and Olcay (2014), TQM is "a management philosophy concerned with people and work processes that focuses on customer satisfaction and improves organizational performance".

Based on a literature review, Terziovski and Samson (1999, p.229) gave TQM the following definition: "TQM is a philosophy that embraces concepts, methods, tools and techniques to form a language which is understood and applied as a business strategy at the 'top-floor' and as a functional strategy at the 'shop-floor'. This approach assists organizations to integrate business activities in leadership, people, customer focus, planning, quality assurance of processes, and information and analysis. These activities when effectively linked together would lead to sustainable world class performance in customer satisfaction, employee relations, operating performance and business performance".

In spite of the multiplicity of definitions given to TQM, most of them share three fundamental principles: customer and stakeholders focus, teamwork and the participation of all the employees of the organisation, process management supported by continuous improvement and learning (Maitah et al., 2014). These three basic principles are evident and simple; they nevertheless remain insufficient for the organisations and cannot provide guidelines in terms of implementation of necessary TQM practices (Maitah et al., 2014). Several authors attempted to suggest valid TQM practices (Flynn et al., 1994; Maitah et al., 2014; Saraph et al., 1989), which led to construct certain known TQM practices identified by their similarities (Lee et al., 2010).

In general, many researchers borrow the six TQM practices developed by the 'Malcolm Baldridge National Quality Award (MBNQA)' model since it is largely used by firms in Europe, USA, Japan and Australia (Samson and Terziovski, 1999), and also because its six practices can be used to evaluate quality improvements in different types of companies (Hart and Schlesinger, 1991); Furthermore they are accepted by many researchers, such as Juran (1995), Evans and Lindsay (1999), Ahire et al. (1995), and 
Dean and Bowen (1994) (Prajogo and Sohal, 2004). Therefore, Table 1 shows the seven TQM practices adopted for this research (Kim et al., 2012; Samson and Terziovski, 1999).

Table 1 TQM practices

\begin{tabular}{|c|c|}
\hline Practices & Description \\
\hline Leadership & $\begin{array}{l}\text { It refers to the extent to which top management sets goals and quality } \\
\text { strategies, allocates resources, contributes to the quality improvement efforts } \\
\text { and evaluates the quality returns. }\end{array}$ \\
\hline $\begin{array}{l}\text { Customer } \\
\text { orientation }\end{array}$ & $\begin{array}{l}\text { As the way an organisation determines the needs and expectations of its actual } \\
\text { and potential customers, ensures an efficient customer relationship } \\
\text { management and measures the customer satisfaction. }\end{array}$ \\
\hline $\begin{array}{l}\text { Strategic } \\
\text { planning }\end{array}$ & $\begin{array}{l}\text { This element focuses on the planning and deployment of strategic and } \\
\text { operational plans of the organisation while paying attention to the } \\
\text { requirements of the customer and the operational performance of the } \\
\text { organisation. }\end{array}$ \\
\hline $\begin{array}{l}\text { Employee } \\
\text { management }\end{array}$ & $\begin{array}{l}\text { It reflects the harmony between human resources practices and the strategic } \\
\text { orientations of the organisation, as in the training and team development, } \\
\text { communication, security, adaptation and flexibility of the employees as well } \\
\text { as their responsibility and satisfaction. }\end{array}$ \\
\hline $\begin{array}{l}\text { Information } \\
\text { and analysis }\end{array}$ & $\begin{array}{l}\text { It concerns the application field of the data and the information's management } \\
\text { and usage in order to maintain a focus on the customer deliver quality } \\
\text { excellence and improve the performance. TQM's philosophy tends to make } \\
\text { decision-making based on facts that imply an analysis of information about } \\
\text { customer needs, operational problems, and the success of the attempts made to } \\
\text { improve. }\end{array}$ \\
\hline $\begin{array}{l}\text { Process } \\
\text { management }\end{array}$ & $\begin{array}{l}\text { The basic idea of this TQM principle is that organisations are a set of } \\
\text { dynamically interrelated processes; their improvement is considered the } \\
\text { bedrock of all performance improvement. }\end{array}$ \\
\hline $\begin{array}{l}\text { Supplier } \\
\text { quality } \\
\text { management }\end{array}$ & $\begin{array}{l}\text { Refers to the extent to which an organisation depends on fewer suppliers, is } \\
\text { interdependent with suppliers, emphasises quality rather than price in } \\
\text { purchasing policy, and supports suppliers in product development. }\end{array}$ \\
\hline Source: & $\begin{array}{l}\text { Deming (1986), Saraph et al. (1989), Evans and Lindsay (1993) and } \\
\text { Terziovski and Samson (1999) }\end{array}$ \\
\hline
\end{tabular}

\subsection{Corporate social responsibility}

The concept of CSR appeared in the 1950s when we began to be aware that there should be a tight link between the actions of the organisations and the environment, actions through which they must confirm and satisfy the social values and expectations. Carroll (1979) considers CSR to be the social expectations of societies at given times, including economic responsibility, legal responsibility, ethical and philanthropic responsibilities (Huang et al., 2014). Economic responsibility is the most fundamental responsibility of every firm, it indicates the way firms should efficiently use resources and provide products at reasonable prices, maintain a fair and stable order for industrial competition, and satisfy the interests and needs of stakeholders in order to create employment, profit and economic growth (Carroll, 2006; Rego et al., 2010). Legal responsibility is the minimal responsibility of the firms, they should respect and incorporate legal regulations in their operational and managerial methods, including obligations concerning 
manufacture, material consumption, work safety and the protection of the environment, so as to avoid harming stakeholders (Carroll, 2006; Maignan, 2001; Maignan and Ferrell, 2000; Ramasamy and Yeung, 2009). Ethical responsibility refers to the conformity between basic cultural values of the firm and moral norms of the society (social expectations and prohibitions), in order to protect the rights and public properties of stakeholders (Branco and Rodrigues, 2006; Carroll, 2006; Maignan, 2001). Philanthropic responsibility represents the firm's activities beyond economic, legal and ethical norms; it is the asset restored to society for the purpose of improving the quality of life, sustaining national policy, and creating a harmonious society (Carroll, 1998; Maignan, 2001).

The CSR concept's definition remains a topic of debate, there is no formal definition of the CSR concept has been agreed upon, there are common definitions that have become rather well used (Kim et al., 2014). The World Business Council for Sustainable Development (2008) defines CSR: "as corporate commitment to the continued fulfillment of moral norms, contribution to economic development, as well as improvement of the quality of life for employees, their families, the overall local community, and society" (Huang et al., 2014). The European Union refers to CSR as a concept whereby firms voluntarily integrate social and environmental preoccupations to their commercial activities and their relations with stakeholders. Companies adopt a socially responsible behaviour when they go beyond the minimum of legal requirements and obligations imposed by collective agreements to meet the societal needs. CSR allows firms, whatever their size is, to contribute to combining economic, social and environmental ambitions in cooperation with their partners (Maignan and Ferrell, 2000). The norm ISO 26000:2010 conceives CSR in a definition that includes, all at once, the ethical vision defended by the Americans, the stakeholders' oriented approach defended by the British, the necessary respect for the law among Europeans, the contribution to sustainable development and the respect for international norms of behaviour strongly defended by French people (Aubrun et al., 2010). For ISO 26000:2010, the responsibility of an organisation for the impacts of its decision and activities on society and the environment, through transparency and ethical behaviour.

The different definitions of CSR presented by academic researchers over the past few decades are multiple but rarely correspond with each other. Through the analysis of 37 definitions of CSR, Dahlsrud (2008) found five main dimensions shared by all those studied definitions, namely: stakeholders dimension, social dimension, economic dimension, environmental dimension and voluntary dimension. This structure developed by Dahlsrud (2008) seems to be quite global and complete, discussing major aspects that can possibly be considered by CSR. Indeed, in order to carry out our study of the CSR's concept, our research borrows these five dimensions.

\subsection{Innovation capability}

Innovation capability, also named 'innovativeness' (Calantone et al., 2002), is a key success factor that allows firms to maintain a long-term competitive advantage vis-à-vis their competitors while improving their performance in a dynamic environment (Sher and Yang, 2005). Innovation capability is a multidimensional concept with multiple definitions. Wonglimpiyarat (2010) and Romijn and Albaladejo (2002) associate innovation capability to the skills and expertise necessary to efficiently absorb, master and improve the existing technologies so as to create new ones, they also see it as a firm's capability to create knowledge such as intellectual property, and to implement applicable 
knowledge and creative ideas to generate value on the market. Koc (2007) considers innovation capability as the continuous improvement of firm's capacities and resources in order to explore and exploit new product development opportunities to meet market needs (Hogan et al., 2011). Xu et al. (2008) define innovation capability as the firm's ability to have access to the development and implementation of innovative technologies with the purpose of conception and production. For Chen (2009), innovation capability of an organisation is the set of capacities ingrained in its processes, systems, and organisational structures, and that can be applied to activities of product or process innovation. Otherwise, for Saunila (2014), innovation capability includes the aspect that has an influence on a firm's capability to manage innovation.

Liao et al. (2007), who define innovation capability as the firm's performance resulting from different types of innovations to achieve a global improvement of its innovation capacity, build it in three dimensions:

1 product innovation

2 process innovation

3 managerial innovation.

Marques and Ferreira (2009) attributes four dimensions to innovation capability:

1 product innovation

2 process innovation

3 market innovation

4 organisational innovation.

Other researchers (Lee and Hsieh, 2010; SaeedSadrMansoori et al., 2013) also divide it to

1 product innovation

2 process innovation

3 managerial innovation

4 marketing innovation.

Lawson and Samson (2001) consider innovation capability as a structure of seven dimensions:

1 vision and strategy

2 harnessing the competence base

3 organisational intelligence

4 creativity and idea management

5 organisational structures and systems

6 culture and climate

7 technology management. 
Yam et al. (2004) have adopted a functional approach to regroup innovation capability in six dimensions, except for the organisational learning capability that represents a separate function,

1 research and development

2 production

3 marketing

4 organisation

5 resource allocation

6 strategic planning.

$\mathrm{Li}$ and Chen (2010) built a model that includes the most important dimensions of innovation capability that influence the performance of developing new products, such as

1 technology

2 organisation

3 strategy

4 production

5 marketing.

Martínez-Román et al. (2011) suggest another vision of three dimensions:

1 knowledge

2 organisation

3 human factor.

The definition advanced by SaeedSadrMansoori et al. (2013) "the ability to continuously transform knowledge and ideas into new products, processes and systems for the benefit of the firm and its stakeholders. Innovation capability is not just an ability to be successful at running a business new-stream, or to manage mainstream capabilities. Innovation capability is about synthesizing these two operating paradigms", seems quite complete since it includes the principle of stakeholders that is a key concept in the CSR definitions.

Concerning the innovation capability's dimensions, we are keeping the seven dimensions (see Table 2) developed by Saunila (2014) to study the impact of innovation capability on the operational and social performance of the firm, as it deals with innovation capability as certain organisational aspects likely to back different types of innovations, contrary to the most researchers that limit the innovation capability to the outputs obtained, whether it's process innovation, product innovation, managerial innovation, etc. 
Table 2 Innovation capability dimensions

\begin{tabular}{|c|c|}
\hline Dimensions & Description \\
\hline $\begin{array}{l}\text { Participatory } \\
\text { leadership culture }\end{array}$ & $\begin{array}{l}\text { Refers to the organisation's overall atmosphere that backs and motivates } \\
\text { innovation, and the leadership that facilitates it. }\end{array}$ \\
\hline $\begin{array}{l}\text { Work climate and } \\
\text { wellbeing }\end{array}$ & $\begin{array}{l}\text { Represent the wellbeing of the employees and further the work climate } \\
\text { for innovation development, including collaboration and values. }\end{array}$ \\
\hline $\begin{array}{l}\text { Ideation and } \\
\text { structures } \\
\text { organisation }\end{array}$ & $\begin{array}{l}\text { Are linked to the structures and systems required for a successful } \\
\text { innovation. This includes generating, developing and implementing } \\
\text { innovations, and the ways how tasks are managed within the } \\
\text { organisation. }\end{array}$ \\
\hline $\begin{array}{l}\text { Know-how } \\
\text { development }\end{array}$ & $\begin{array}{l}\text { It includes knowledge and skills of the employees who play an important } \\
\text { role in innovation capability. This includes the use of knowledge as well } \\
\text { as the improvement of the employees' skills, and the understanding of } \\
\text { the external environment, including customers, competitors and emerging } \\
\text { technology (Calantone et al., 2002; Keskin, 2006). }\end{array}$ \\
\hline External knowledge & $\begin{array}{l}\text { It highlights the importance of proper conduct in terms of exploiting } \\
\text { external networks, inter-firms connections, and knowledge to the overall } \\
\text { organisational innovation capability. }\end{array}$ \\
\hline Regeneration & $\begin{array}{l}\text { Reflects an organisation's ability to learn from earlier experiences and } \\
\text { exploiting them to create innovations and develop their operations. }\end{array}$ \\
\hline Individual activity & $\begin{array}{l}\text { Employees' individual innovation capability and activity are needed to } \\
\text { form the organisation's overall innovation capability, which forms the } \\
\text { employee activity aspect. }\end{array}$ \\
\hline
\end{tabular}

Source: Saunila (2014)

\subsection{Financial performance}

Financial performance measurement knows a great diversity between authors. Thus, it presents anomalies concerning the comparison and generalisation of the results. Two major categories of financial performance measurement exist; they are quite used in the majority of studies, the first category is based upon accounting indicators that provide an image of the history of the firm's profitability [return on assets (ROA), return on equity (ROE), and return on sales (ROS), etc.]. Whereas the other category is based upon a range of indicators concerning the stock market and which refer to the shareholders' and investors' expectations and evaluations of the firm's profitability [total return to shareholders, variations of share price, stock market performance, price earnings ratio (PER), and book to market ratio, etc.].

In spite of the limitations presented by these two categories of financial performance measurement indicators, the authors demonstrate that the accounting indicators are most efficient to measure financial performance (Simpson and Kohers, 2002; Waddock and Graves, 1997). For example, in the relation between social and financial performance, Mcguire et al. (1988) and Orlitzky et al. (2003) stipulate that accounting measurements turned out to be better preachers of the CSR (Allouche and Laroche, 2011). In their view, and whilst studying the link between innovation performance and financial performance, Kostopoulos et al. (2011) chose the ROS and the ROA to measure financial performance. According to these researchers, ROS and ROA are two very popular indicators of profitability that are taken into consideration by the firms when evaluating their decisions and strategic goals. According to an article (Hagel et al., 2010) published in the Harvard 
Business Review, the best way to measure the firm's performance is through the ROA because it explicitly into consideration all the assets used to sustain commercial activities. It determines whether the firm is able to generate an adequate return on its assets rather than only reflect solid returns on sales.

Taking into account that most of the anterior theoretical and empirical studies use accounting data in the measurement of financial performance as opposed to measures based upon stock market, in this paper, we get back to assets (ROA), equity (ROE), and back to sales (ROS) as indicators of financial performance.

\section{Theoretical framework and development of research hypotheses}

\subsection{Bidirectional link CSR-innovation capability}

Innovation and CSR are considered as major contemporary issues (Labelle, 2008), the relationship between these two strategic orientations generally takes two different senses, the first is the fact that CSR practices might be an antecedent to innovation (MacGregor and Bianchi, 2007; Ubius and Alas, 2012). Thus, CSR can lead to innovation through a respect of the stakeholders' environmental, social and sustainable requirements. Being open towards all stakeholders encourages firms to initiate new working ways, create new products/services, processes and new market areas (Little, 2006). Ubius and Alas (2012) established a link between CSR and the innovation climate in a firm and found out that CSR predicts the climate of innovation for different specified age groups of employees. Bocquet and Mothe (2013) have studied the relationship between CSR and innovation in the SMEs context; the results obtained indicate that a reactive CSR approach leads to developing incremental product innovation whereas a strategic CSR allows for radical product innovation. The reactive CSR represents the firm's response to constraints or pressures from its stakeholders, while the strategic CSR requires alignment between CSR practices and business strategy, creating a virtuous circle for innovation activities to grow and rich competitiveness (Bocquet and Mothe, 2013; Porter and Kramer, 2006). Luo and $\mathrm{Du}$ (2015), by combining the literature on CSR and the knowledge-based View, empirically stated that firms with greater CSR activities are recognised to be the best tend to have a higher innovation capability and introduce pioneering and incremental new products more often.

The second sense considered the relation CSR-innovation conversely; some authors took an interest in the role played by innovation in the integration of the firm in a CSR approach. Le Bas et al. (2010) demonstrated the existence of a significant strong relationship between the firm's achievements of a product or process innovations, and its involvement in a CSR approach. They have found that engaging in technological innovations is a behaviour which is positively associated with each of the CSR dimensions (economic, social, and environmental). In other words, the more a firm is innovative, the more it will have a strong tendency to implement CSR approaches (Temri et al., 2012).

This two-way relationship between innovation and CSR was extensively examined in separate in literature, only a few authors (Gallego-Álvarez et al., 2011; MacGregor and Fontrodona, 2008; Midttun, 2007) have tried to join them in the same study and suggest a model in the form of a virtuous loop including both CSR and innovation in the same approach. These authors confirm the bidirectional relationship between CSR and 
innovation even if the modus operandi of this model is not deeply explained. According to MacGregor and Fontrodona (2008), on one side, CSR can be innovation-oriented 'CSR-driven innovation' when it's stimulated by values and results in products/services of a social nature, it's about 'doing the right things'. On the other side, innovation can be CSR-oriented 'innovation-driven CSR' when it's seeking value creation through the firm's social processes, and the final result can only have a unique social justification, in this case, it's more about 'doing things right'.

Temri et al. (2012) stipulate that being committed to sustainable development is reflected through an innovative behaviour, but it's also interesting to recognise that innovative companies are also the most involved in terms of CSR, in a concomitant way. Contrarily, Gallego-Álvarez et al. (2011) show that the bidirectional link between these two strategic decisions is negative, according to these researchers, all of the CSR practices cannot create value for the firm. In case a firm is strategically using CSR to attract customers, it seems that firms offering the most developed products to their customers do not need anything else to attract them. Based on this discussion, we are suggesting the following hypotheses:

H1 There is a bidirectional link between CSR and innovation.

H1a being involved in CSR approaches allows the firm to have a strong innovation capability.

H1b a strong innovation capability allows the firm to implement CSR approaches.

\subsection{TQM and the bidirectional link CSR-innovation capability}

Literature on CSR and quality management has evolved in a separate way; However, a small but nevertheless growing number of studies concerning their intersection emerges (Hollingworth and Valentine, 2014), obtained results concerning the link between TQM and CSR remains controversial although the majority of researchers claim the compatibility between their practices (Hazlett et al., 2007; Hollingworth and Valentine, 2014; Kok et al., 2001; McAdam and Leonard, 2003). For example, CSR principles are coherent with quality management principles of continuous improvement, organisational commitment, customer orientation and stakeholder orientation (Frolova and Lapina, 2014). According to Hollingworth and Valentine (2014), there is a strong link between CSR and the continuous improvement dimension of TQM, since they share common principles such as rationality, information sharing, cooperation, involvement and employees' commitment, common vision and shared goals, stakeholder orientation, as well as a long-term perspective (Detert et al., 2000; Kok et al., 2001; Rothschild, 2000).

McAdam and Leonard (2003) suggest that inherent values of quality management are very similar to those of CSR and that compatible ethical values provide a common base for both quality management and CSR, it's the ethical foundation of TQM that explains the way it can back up the implementation of CSR in the organisations, because according to Juran and Gryna (1993), TQM should be recognised for its emphasis on human resource through the quality of the employees' working life and their satisfaction, this basic principle of quality is a key factor in its identification as a key area in terms of CSR (McAdam and Leonard, 2003). Benavides-Velasco et al. (2014) have examined the influence of TQM and CSR's implementation on the performance of Spanish hotels; they confirm that the CSR's level of development is positively affected by the implementation of TQM, this statement is aligned with that of Zink (2007) who argue that quality 
management models present a base and serve as a catalyst for the CSR's efficiency in organisations.

Vinten (1998) argues that TQM is - historically and actually - compatible with both ethical and instrumental sides of CSR; this coherence eventually allows CSR to be incorporated into the organisation in a more efficient way and in a short period of time building on organisational changes, in the behaviour and processes of the firm introduced by TQM (McAdam and Leonard, 2003). Castka and Balzarova (2007) suggest that CSR and corporate governance being currently taken into consideration stands as an opportunity for the quality movement and its practitioners to add more value to their organisations. Quality standards, excellence models (such as EFQM, MBNQA, etc.) and TQM principles can serve as platforms for the implementation of CSR in organisations.

Prajogo and Sohal (2003) presented a large literature review on the relationship between TQM and the innovation performance; they identified the existence of two contradictory arguments concerning the nature of this relationship. The first suggests that TQM is positively linked to the innovation performance, explained by the fact that TQM embodies principles and practices compatible with innovation, creating a fertile environment that backs the innovation capability (Prajogo and Sohal, 2003). For an example, the customer focus principle incites the firm to constantly look for the customers' new needs and expectations; consequently, this leads the firms to innovate through the development and introduction of new products. In addition, the continuous improvement principle encourages change and creativity in the way work is organised and led. Finally, principles of autonomy, implication, and teamwork are also important in the success of organisational innovation.

Contrarily, the second argument admits that TQM is negatively linked to innovation capability because it binds practices and principles that limit the company's flexibility (such as standardisation and formalisation), which could affect innovation. As an example, the customer focus principle doesn't allow the identification of the clients' future needs, the firm will then only focus on incrementally developing its current products without seeking new solutions and implementing real innovations (Slater and Narver, 1998; Wind and Mahajan, 1997). Moreover, the continuous improvement principle can impede employees by blocking them in a routine, rigidity and limiting their creativity, and also the firm by only improving flawed cycles already exist and which would rather lead to weak and unimportant incremental changes to the detriment of radical innovations.

This debate on the relationship between TQM and innovation relatively finds its explanation in the complicated multidimensional aspect of the TQM concept, each of the multiple elements embodied by TQM can have a different influence on innovation. In the same way, the multidimensional aspect of innovation also participates in the ambiguity of this relationship because multiple studies lack clarification of the innovation's dimensions taken into consideration while studying the link TQM-innovation (Prajogo and Sohal, 2001, 2004).

Based on the meta-analysis by Riillo (2014), who examines recent quantitative studies discussing the relationship between quality management (ISO 9000 and TQM) and innovation. Among the sixteen empirical studies analysed, thirteen of them support the positive link between TQM and innovation (Harris et al., 2013; Kim et al., 2012; Perdomo-Ortiz et al., 2006; Prajogo and Sohal, 2003, 2004). While three empirical studies who don't support this link (Feng et al., 2006; Prajogo and Sohal, 2006; Singh 
and Smith, 2004). According to these results, we can consider that the firms adopting TQM can improve their innovation capability.

In the light of the above and of TQM's role in the firm's strategic orientation (Fuentes et al., 2006), we will start from the fact that, on one hand, TQM is a frame for the implementation and development of CSR, and on the other hand, is a way to improve the firm's innovation capability. We thus suppose that TQM can be a platform to back up both CSR and innovation capability simultaneously and at the same time their bidirectional relationship. However, we pose the following hypothesis:

H2 TQM is a platform for the development of the bidirectional link between innovation capability and CSR.

H2a Firms adopting TQM will have a strong innovation capability.

$\mathrm{H} 2 \mathrm{~b}$ Firms adopting TQM will easily engage in CSR approaches.

\subsection{Bidirectional relationship CSR-innovation and financial performance}

The relationship between CSR and financial performance was largely studied in the literature, but the obtained results remain controversial and paradoxical (Waworuntu et al., 2014). The majority of recent theoretical and empirical studies indicate the existence of a positive link (Allouche and Laroche, 2005; Goll and Rasheed, 2004; Hull and Rothenberg, 2008; Moneva et al., 2011; Orlitzky et al., 2003; Van Beurden and Gössling, 2008). A complete study with positive results is the meta-analysis conducted by Orlitzky et al. (2003) on the relationship between social performance or CSR, and financial performance has concluded that they are generally positively correlated with a large variety of industry and study contexts and that they are also related to a causal bidirectional link. That is to say that social performance and financial performance mutually affect each other through a virtuous cycle (Waddock and Graves, 1997), financially successful firms tend to allocate more resource to achieve a social performance and in return, it helps them get a bit more financial returns.

Contradictorily, studies which have found a negative link between CSR and financial performance explain the fact that stakeholders are less likely to be interested in CSR activities considered as useless and avoidable, therefore, their effect is irrelevant and its global impact on the financial aspect will eventually be negative (Brammer et al., 2006; Carroll et al., 1991; López et al., 2007; Mellahi et al., 2010). The authors attribute the explanation of those results that are generally mixed up with the different instruments of CSR measurement and financial performance, and also to the lack of appropriate statistical controls (Brammer et al., 2006; Carroll, 1991; Griffin and Mahon, 1997; Margolis and Walsh, 2003; Ullmann, 1985).

Organisational performance is generally linked to innovation (Brown and Eisenhardt, 1995; Capon et al., 1992; Hull and Rothenberg, 2008; Orlitzky et al., 2003; Zahra and Covin, 1995), the more a firm disposes of a better innovation capability the more its organisational performance is higher (Calantone et al., 2002; Huang et al., 2009; Marques and Ferreira, 2009; Roberts and Amit, 2003). While studying the effects of the firm's capability to generate innovations on the organisational performance (financial and operational), Saunila (2014) found that three aspects of innovation capability, namely ideation and organising structures, participatory leadership culture and expertise development, have an effect on the different aspects of the firm's performance. In 
particular, the aspects of innovation capability have more influence on financial performance than the operational one. In the same sense, the results of Bukhamsin (2015) show that two important aspects of innovation capability, innovation process, and leadership management, are directly and positively associated with financial and operational performance.

Furthermore, It has been demonstrated that managing innovation to survive and grow positively influence firm performance when environmental factors are taken into account (Chandler et al., 2000; Hull and Rothenberg, 2008; Zahra and Covin, 1995; Zahra and Neubaum, 1998). The meta-analysis conducted by Vishwanathan (2010) on the elusive relationship between social and financial performance have also shown that innovation capability, when linked to the firm's social performance, has a positive influence on its financial performance.

Many studies have tried to study the positive influence of CSR and innovation on financial performance, but indeed, there is no study about the impact of both CSR and innovation capability on financial performance. In fact, we believe that the bidirectional link CSR-innovation capability improves the financial performance; we will thus formulate the following hypothesis:

H3 The bidirectional relationship CSR-innovation capability significantly and positively affects the firm's financial performance.

As our theoretical development, Figure 1 will attempt to present the research's conceptual framework model, in order to ensure a simple comprehension of the research question.

Figure 1 Relationship between TQM, CSR, innovation capability, and financial performance

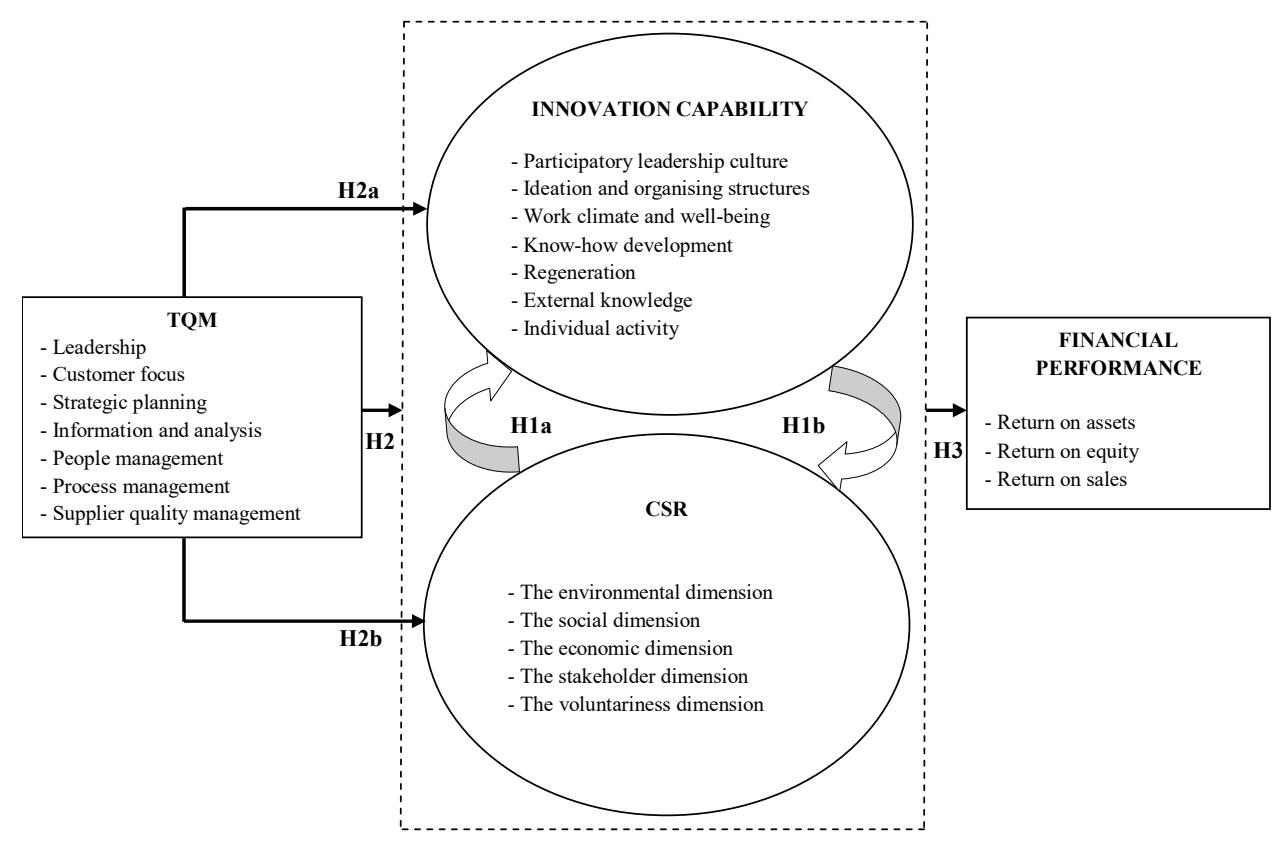




\section{Conclusions}

Building a competitive advantage is a condition for performance. Firms now have to provide their markets with an innovative and high-quality product that respects social and environmental requirements. Indeed, the main objective of our research is to provide a contribution to the theoretical gaps and ambiguities that exist in the literature between three vast fields of research, CSR, innovation and quality management. By falling within the scope of strategic management, our conceptual framework suggests that TQM can catalyse innovation capability and CSR, and serve as a support platform for developing their bidirectional link and this iterative link can have positively an impact on the firm's financial performance.

From a theoretical perspective, our model is a first attempt to bind TQM, CSR, innovation capability and financial performance in a single problematic which aims to deepen the understanding of their relationships. We extend CSR and innovation literature by identifying CSR as a new antecedent to innovation and vice versa. As well, we have already shown that guaranteed business excellence TQM as organisation-wide philosophy could be a starting point for the simultaneous realisation of other strategic orientations of the company like CSR and innovation. In spite of the role of TQM and for more effectiveness, quality management programs (i.e., ISO 9001, EFQM, MBNQA) must be updated and restructured in such a way to support the realisation of innovation and the management of CSR practices.

Obviously, our research has a managerial contribution intended for the professionals' world of firms. It allows managers to understand the possible articulation between CSR, innovation, and use it as a driver of the financial performance of their firms. Managers can consider that expenditures on CSR and innovation are better viewed as capital investments rather than operational costs. Even though, CSR and the operational costs of innovation can be efficiently reduced through the integration of TQM practices.

As in every study, ours also represents limits which should be taken into consideration, and that might stand as new research tracks for the future. First, our paper only focused on some selective bidirectional relationships presented in the conceptual framework. There are other potential bidirectional relationships which can be explored, for example, between TQM and CSR, or TQM and innovation capability (e.g., Brad, 2008; Dimara et al., 2004; Du et al., 2016; Pekovic, 2010). Second, TQM, CSR, and innovation are contingent on firm characteristics and industry condition. The upcoming research has to integrate some other variables as firm size, the level of R\&D investment, competitive intensity, and type of industry.

Overall, the framework developed is in its infancy, before carrying out a confirmatory analysis to test the previous hypotheses, we are inviting researchers to conduct several expanded qualitative studies in order to explore more deeply the relationships between the different variables since these relationships are more complex in reality.

\section{References}

Allouche, J. and Laroche, P. (2011) 'Performance sociale et performance financière: etat de l'art', Proposition de Communication Lors de la 20ème Conférence de l'AIMS 2011 (Nantes).

Aubrun, M., Bermond, E.F., Brun, J-L.C., Delchet-Cochet, K., O. Graffin, A.J. et al. (2010) ISO 26000 - Responsabilité sociétale - Comprendre, déployer, évaluer (AFNOR, Ed.). 
Benavides-Velasco, C.A., Quintana-García, C. and Marchante-Lara, M. (2014) 'Total quality management, corporate social responsibility and performance in the hotel industry', International Journal of Hospitality Management, Vol. 41, pp.77-87.

Bocquet, R. and Mothe, C. (2013) 'Profil des entreprises en matière de RSE et innovation technologique', Management \& Avenir, Vol. 66, No. 8, p.132.

Brad, S. (2008) 'Vectors of innovation to support quality initiatives in the framework of ISO 9001:2000', International Journal of Quality \& Reliability Management, Vol. 25, No. 7, pp.674-693.

Brammer, S., Brooks, C. and Pavelin, S. (2006) 'Corporate social performance and stock returns: UK evidence from disaggregate measures', Financial Management, Vol. 35, No. 3, pp.97-116.

Branco, M.C. and Rodrigues, L.L. (2006) ;Corporate social responsibility and resource-based perspectives', Journal of Business Ethics, Vol. 69, No. 2, pp.111-132.

Brown, S.L. and Eisenhardt, K.M. (1995) 'Product development: past research, present findings, and future directions', The Academy of Management Review, Vol. 20, No. 2, pp.343-378.

Bukhamsin, M. (2015) Investigating the Relationship between Organizational Innovation Capability and Firm Performance with Irish SMEs [online] http://arrow.dit.ie/scschcomdis/61/ (accessed 31 October 2016).

Calantone, R.J., Cavusgil, S.T. and Zhao, Y. (2002) 'Learning orientation, firm innovation capability, and firm performance', Industrial Marketing Management, Vol. 31, No. 6, pp.515-524.

Capon, N., Farley, J.U., Lehmann, D.R. and Hulbert, J.M. (1992) 'Profiles of product innovators among large U.S. manufacturers', Management Science, Vol. 38, No. 2, pp.157-169.

Carroll, A.B. (1979) 'A three-dimensional conceptual model of corporate performance', The Academy of Management Review, Vol. 4, No. 4, pp.497-505.

Carroll, A.B. (1991) 'The pyramid of corporate social responsibility: toward the moral management of organizational stakeholders', Business Horizons, Vol. 34, No. 4, pp.39-48.

Carroll, A.B. (1998) 'The four faces of corporate citizenship', Business and Society Review, Vol.100-101, No. 1, pp.1-7.

Carroll, A.B., López, M.V., Garcia, A. and Rodriguez, L. (1991) 'The pyramid of corporate social responsibility: toward the moral management of organizational stakeholders', Journal of Business Ethics, Vol. 34, No. 3, pp.285-300.

Castka, P. and Balzarova, M.a. (2007) 'A critical look on quality through CSR lenses: key challenges stemming from the development of ISO 26000', International Journal of Quality \& Reliability Management, Vol. 24, No. 7, pp.738-752.

Chandler, G.N., Keller, C. and Lyon, D.W. (2000) 'Unravelling the determinants and consequences of an innovation-supportive organizational culture', Entrepreneurship Theory and Practice, Vol. 25, No. 1, pp.59-76.

Chen, C-J. (2009) ; Technology commercialization, incubator and venture capital, and new venture performance', Journal of Business Research, Vol. 62, No. 1, pp.93-103.

Cochran, P.L. and Wood, R.A. (1984) 'Corporate social responsibility and financial performance', Academy of Management Journal, Vol. 27, No. 1, pp.42-56.

Curkovic, S. (2003) 'Environmentally responsible manufacturing: the development and validation of a measurement model', European Journal of Operational Research, Vol. 146, No. 1, pp.130-155.

Dahlsrud, A. (2008) 'How corporate social responsibility is defined: an analysis of 37 definitions', Corporate Social Responsibility and Environmental Management, Vol. 15, No. 1, pp.1-13.

Deming, W.E. (1986) Out of the Crisis, Bloomsbury Business Library - Management Library.

Detert, J.R., Schroeder, R.G. and Mauriel, J.J. (2000) 'A framework for linking culture and improvement initiatives in organizations', Academy of Management Review, Vol. 25, No. 4, pp.850-863. 
Dhiaf, M. (2007) 'Proposition d'un modèle de mesure de l'impact du total quality management sur la performance globale: cas des entreprises tunisiennes de textile-habillement', Arts et Métiers ParisTech.

Dimara, E., Skuras, D., Tsekouras, K. and Goutsos, S. (2004) 'Strategic orientation and financial performance of firms implementing ISO 9000', International Journal of Quality \& Reliability Management, Vol. 21, No. 1, pp.72-89.

Du, Y., Yin, J. and Zhang, Y. (2016) 'How innovativeness and institution affect ISO 9000 adoption and its effectiveness: evidence from small and medium enterprises in China', Total Quality Management \& Business Excellence, Vol. 27, Nos. 11-12, pp.1315-1331.

Evans, J. and Lindsay, W. (1993) The Management and Control of Quality, 2nd ed., West Pub. Co., Minneapolis, Minnesota.

Feng, J., Prajogo, D.I., Tan, K.C. and Sohal, A.S. (2006) 'The impact of TQM practices on performance - a comparative study between Australian and Singaporean organizations', European Journal of Innovation Management, Vol. 9, No. 3, pp.269-278.

Flynn, B.B., Schroeder, R.G. and Sakakibara, S. (1994) 'A framework for quality management research and an associated measurement instrument', Journal of Operations Management, Vol. 11, No. 4, pp.339-366.

Frolova, I. and Lapina, I. (2014) 'Corporate social responsibility in the framework of quality management', Procedia - Social and Behavioral Sciences, Vol. 156, pp.178-182.

Fuentes, M.M.F., Montes, F.J.L., Fernández, L.M.M., Llorens Montes, F.J. and Fernandez, L.M. (2006) 'Total quality management, strategic orientation and organizational performance: the case of Spanish companies', Total Quality Management \& Business Excellence, Vol. 17, No. 3, pp.303-323.

Gallego-Álvarez, I., Manuel Prado-Lorenzo, J. and García-Sánchez, I-M. (2011) 'Corporate social responsibility and innovation: a resource-based theory', Management Decision, Vol. 49, No. 10, pp.1709-1727.

Goll, I. and Rasheed, A.A. (2004) 'The moderating effect of environmental munificence and dynamism on the relationship between discretionary social responsibility and firm performance', Journal of Business Ethics, Vol. 49, No. 1, pp.41-54.

Griffin, J.J. and Mahon, J.F. (1997) 'The corporate social performance and corporate financial performance debate: twenty-five years of incomparable research', Business \& Society, Vol. 36, No. 1, pp.5-31.

Hagel, J. III, Brown, J.S. and Davison, L. (2010) The Best Way to Measure Company Performance [online] https://hbr.org/2010/03/the-best-way-to-measure-compan.html (accessed 03 September 2016).

Harris, R., McAdam, R., McCausland, I. and Reid, R. (2013) 'Levels of innovation within SMEs in peripheral regions: the role of business improvement initiatives', Journal of Small Business and Enterprise Development, Vol. 20, No. 1, pp.102-124.

Hart, C. and Schlesinger, L. (1991) 'Total quality management and the human resource professional: applying the baldrige framework to human resources', Human Resource Management, Vol. 30, No. 4, pp.433-454.

Hazlett, S-A., McAdam, R. and Murray, L. (2007) 'From quality management to socially responsible organisations: the case for CSR', International Journal of Quality \& Reliability Management, Vol. 24, No. 7, pp.669-682.

Hogan, S.J., Soutar, G.N., McColl-Kennedy, J.R. and Sweeney, J.C. (2011) 'Reconceptualizing professional service firm innovation capability: scale development', Industrial Marketing Management, Vol. 40, No. 8, pp.1264-1273.

Hollingworth, D. and Valentine, S. (2014) 'Corporate social responsibility, continuous process improvement orientation, organizational commitment and turnover intentions', International Journal of Quality \& Reliability Management, Vol. 31, No. 6, pp.629-651. 
Huang, C-C., Yen, S-W., Liu, C-Y. and Huang, P-C. (2014) 'The relationship among corporate social responsibility, service quality, corporate image and purchase intention', International Journal of Organizational Innovation, Vol. 6, No. 3, pp.68-85.

Huang, S.Y., Hung, Y.C., Lin, C.C. and Tang, I.J. (2009) 'The effects of innovative capacity and capital expenditures on financial performance', International Journal of Innovation and Learning, Vol. 6, No. 3, p.323.

Hull, C.E. and Rothenberg, S. (2008) 'Firm performance: the interactions of corporate social performance with innovation and industry differentiation', Strategic Management Journal, Vol. 29, No. 7, pp.781-789.

Juran, J.M. and Gryna, F.M. (1993) Quality Planning and Analysis: From Product Development Through Use (third).

Keskin, H. (2006) 'Market orientation, learning orientation, and innovation capabilities in SMEs: an extended model', European Journal of Innovation Management, Vol. 9, No. 4, pp.396-417.

Kim, D., Kumar, V. and Kumar, U. (2012) 'Relationship between quality management practices and innovation', Journal of Operations Management, Vol. 30, No. 4, pp.295-315.

Kim, Y., Brodhag, C. and Mebratu, D. (2014) 'Corporate social responsibility driven innovation', Innovation: The European Journal of Social Science Research, Vol. 27, No. 2, pp.175-196.

Koc, T. (2007) 'Organizational determinants of innovation capacity in software companies', Computers and Industrial Engineering, Vol. 53, No. 3, pp.373-385.

Kok, P., Van Der Wiele, T., McKenna, R. and Brown, A. (2001) 'A corporate social responsibility audit within a quality management framework', Journal of Business Ethics, Vol. 31, No. 4, pp.285-297.

Kostopoulos, K., Papalexandris, A., Papachroni, M. and Ioannou, G. (2011) 'Absorptive capacity, innovation, and financial performance', Journal of Business Research, Vol. 64, No. 12, pp.1335-1343.

Labelle, F. (2008) 'La PME et la durabilité : une gestion qui améliore les capacités d'innovation des entrepreneurs', 9ème Congrès Int. Francoph. en Entrep. PME, du 28 au 31 Octobre, Louvain-la-Neuve, Belgique.

Lawson, B. and Samson, D. (2001) 'Developing innovation capability in organisations: a dynamic capabilities approach', International Journal of Innovation Management, Vol. 5, No. 3, pp.377-400.

Le Bas, C., Poussing, N. and Haned, N. (2010) 'Innovation, leadership technologique et comportements de responsabilité sociale: une exploration sur données d'entreprises', Economie Du Système de Créativité Des Inventeurs Prolifiques.

Lee, J-S. and Hsieh, C-J. (2010) 'A research in relating entrepreneurship, marketing capability, innovative capability and sustained competitive advantage', Journal of Business \& Economics Research, Vol. 8, No. 9, pp.109-119.

Lee, V.H., Ooi, K.B., Tan, B.I. and Chong, A.Y.L. (2010) 'A structural analysis of the relationship between TQM practices and product innovation', Asian Journal of Technology Innovation, Vol. 18, No. 1, pp.73-96.

Li, Q. and Chen, Y. (2010) 'The effects of innovation capability on new product development performance: the evidence of Zhejiang province' SMEs', 2010 International Conference on Management and Service Science, IEEE, No. 4, pp.1-5.

Liao, S-h., Fei, W-C. and Chen, C-C. (2007) 'Knowledge sharing, absorptive capacity, and innovation capability: an empirical study of Taiwan's knowledge-intensive industries', Journal of Information Science, Vol. 33, No. 3, pp.340-359.

Little, A.D. (2006) 'The innovation high ground: Winning tomorrow's customers using sustainability-driven innovation', Strategic Direction, Vol. 22, No, 1, pp.35-37.

López, M.V., Garcia, A. and Rodriguez, L. (2007) 'Sustainable development and corporate performance: a study based on the dow jones sustainability index', Journal of Business Ethics, Vol. 75, No. 3, pp.285-300. 
Luo, X. and Du, S. (2015) 'Exploring the relationship between corporate social responsibility and firm innovation', Marketing Letters, Vol. 26, No. 4, pp.703-714.

MacGregor, S.P. and Bianchi, M. (2007) 'Towards the tipping point for social innovation', 2nd International Conference on Towards Sustainable Product Design (Sustainable Innovation 07), Farnham, Surrey, UK.

MacGregor, S.P. and Fontrodona, J. (2008) 'Exploring the fit between CSR and innovation', SSRN Electronic Journal, Vol. 3, p.23.

Mahmud, N. and Hilmi, M.F. (2014) 'TQM and Malaysian SMEs performance: the mediating roles of organization learning', 4th International Conference on Marketing and Retailing 2013, INCOMaR 2013, Procedia - Social and Behavioral Sciences, Vol. 130, pp.216-225.

Maignan, I. (2001) 'Consumers' perceptions of corporate social responsibilities: a cross-cultural comparison', Journal of Business Ethics, Vol. 30, No. 1, pp.57-72.

Maignan, I. and Ferrell, O.C. (2000) 'Measuring corporate citizenship in two countries: the case of the United States and France', Journal of Business Ethics, Vol. 23, No. 3, pp.283-297.

Maitah, M., Hodrab, R. and Melad, A. (2014) 'The impact of quality management practices on firm's performance an empirical investigation of associated constructs in Palestinian information and communication technology firms', International Business Management, Vol. 8, No. 6, pp.312-326.

Margolis, J. and Walsh, J. (2003) 'Misery loves rethinking companies: social initiatives by business', Administrative Science Quarterly, Vol. 48, No. 2, pp.268-305.

Marques, C.S. and Ferreira, J. (2009) 'SME innovative capacity, competitive advantage and performance in a 'traditional' industrial region of Portugal', Journal of Technology Management and Innovation, Vol. 4, No. 4, pp.53-68.

Martínez-Costa, M. and Martínez-Lorente, A. (2008) 'Does quality management foster or hinder innovation? An empirical study of Spanish companies', Total Quality Management \& Business Excellence, Vol. 19, No. 3, pp.209-221.

Martínez-Román, J.A., Gamero, J. and Tamayo, J.A. (2011) 'Analysis of innovation in SMEs using an innovative capability-based non-linear model: a study in the province of Seville (Spain)', Technovation, Vol. 31, No. 9, pp.459-475.

McAdam, R. and Leonard, D. (2003) 'Corporate social responsibility in a total quality management context: opportunities for sustainable growth', Corporate Governance, Vol. 3, No. 4, pp.36-45.

Mcguire, J.B., Sundgren, A. and Schneeweis, T. (1988) 'Corporate social responsibility and firm financial performance', Academy of Management Journal, Vol. 31, No. 4, pp.854-872.

McWilliams, A. and Siegel, D. (2000) 'Corporate social responsibility and financial performance: correlation or misspecification?', Strategic Management Journal, Vol. 21, No. 5, pp.603-609.

Mellahi, K., Morrell, K. and Wood, G. (2010) The Ethical Business: Challenges and Controversies, 2nd ed., Palgrave Macmillan.

Midttun, A. (2007) 'Towards a dynamic reinterpretation of C(S)R: are corporate responsibility and innovation compatible or contradictory?', Corporate Governance, Vol. 7, No. 4, pp.401-413.

Moneva, J.M., Rivera-Lirio, J.M., Muñoz-Torres, M.J., Van Beurden, P., Gössling, T. et al. (2011) 'Corporate social responsibility (CSR) and financial performance (FP): case of French SMEs', International Council for Small Business (ICSB), Washington, Vol. 24, No. 1, pp.1-23.

Nollet, J., Filis, G. and Mitrokostas, E. (2016) 'Corporate social responsibility and financial performance: a non-linear and disaggregated approach', Economic Modelling, Vol. 52, No. 1, pp.400-407.

Orlitzky, M., Schmidt, F.L. and Rynes, S.L. (2003) 'Corporate social and financial performance: a meta-analysis', Organization Studies, Vol. 24, No. 1, pp.403-441.

Pekovic, S. (2010) 'The determinants of ISO 9000 certification: a comparison of the manufacturing and service sectors', Journal of Economic Issues, No. 4, pp.895-914. 
Perdomo-Ortiz, J., González-Benito, J., Galende, J., Gonza, J. and Galende, Ã. (2006) 'Total quality management as a forerunner of business innovation capability', Technovation, Vol. 26, No. 10, pp.1170-1185.

Porter, M.E. and Kramer, M.R. (2006) 'Strategy \& society: the link between competitive advantage and corporate social responsibility', Harvard Business Review, Vol. 84, No. 12, pp.78-92.

Porter, M.E. and Tanner, S. (2001) 'Assessing business excellence', in O. Elsevier Butterworth-Heinemann (Ed.): A Guide to Business Excellence and Self-Assessment.

Prajogo, D.I. and Sohal, A.S. (2001) 'TQM and innovation: a literature review and research framework', Technovation, Vol. 21, No. 9, pp.539-558.

Prajogo, D.I. and Sohal, A.S. (2003) 'The relationship between TQM practices, quality performance, and innovation performance: an empirical examination', International Journal of Quality \& Reliability Management, Vol. 20, No. 8, pp.901-918.

Prajogo, D.I. and Sohal, A.S. (2004) 'The multidimensionality of TQM practices in determining quality and innovation performance - an empirical examination', Technovation, Vol. 24, No. 6, pp.443-453.

Prajogo, D.I. and Sohal, A.S. (2006) 'The integration of TQM and technology/R\&D management in determining quality and innovation performance', Omega, Vol. 34, No. 3, pp.296-312.

Ramasamy, B. and Yeung, M. (2009) 'Chinese consumers' perception of corporate social responsibility (CSR)', Journal of Business Ethics, Vol. 88, Supplementary 1, pp.119-132.

Rego, A., Leal, S., Cunha, M.P., Faria, J. and Pinho, C. (2010) 'How the perceptions of five dimensions of corporate citizenship and their inter-inconsistencies predict affective commitment', Journal of Business Ethics, Vol. 94, No. 1, pp.107-127.

Riillo, C.A.F. (2014) 'Quality management and innovation: a review of quantitative studies', International Journal of Productivity and Quality Management, Vol. 14, No. 4, p.441.

Roberts, P.W. and Amit, R. (2003) 'The dynamics of innovative activity and competitive advantage: the case of Australian retail banking, 1981 to 1995', Organization Science, Vol. 14, No. 2, pp.107-122.

Romijn, H. and Albaladejo, M. (2002) 'Determinants of innovation capability in small electronics and software firms in southeast England', Research Policy, Vol. 31, No. 7, pp.1053-1067.

Rothschild, J. (2000) 'Creating a just and democratic workplace: more engagement, less hierarchy', Contemporary Sociology.

Rungtusanatham, M., Forza, C., Koka, B.R., Salvador, F. and Nie, W. (2005) 'TQM across multiple countries: convergence hypothesis versus national specificity arguments', Journal of Operations Management, Vol. 23, No. 1, pp.43-63.

Sadikoglu, E. and Olcay, H. (2014) 'The effects of total quality management practices on performance and the reasons of and the barriers to TQM practices in Turkey', Advances in Decision Sciences, pp.1-17.

SaeedSadrMansoori, A.S, Shafiei, M. and SedigehAfrooz, M. (2013) 'A research in relationship between entrepreneurship, marketing capability, innovative capability and sustainable competitive advantage Kaveh industrial city 2012-2013', Advances in Environmental Biology, Vol. 7, No. 8, pp.1490-1497.

Samson, D. and Terziovski, M. (1999) 'The relationship between total quality management practices and operational performance', Journal of Operations Management, Vol. 17, No. 4, pp.393-409.

Saraph, J.V., Benson, P.G. and Schroeder, R.G. (1989) 'An instrument for measuring the critical factors of quality management', Decision Sciences, Vol. 20, No. 4, pp.810-829.

Saunila, M. (2014) 'Innovation capability for SME success: perspectives of financial and operational performance', Journal of Advances in Management Research, Vol. 11, No. 2, pp. $163-175$.

Sher, P.J. and Yang, P.Y. (2005) 'The effects of innovative capabilities and R\&D clustering on firm performance: the evidence of Taiwan's semiconductor industry', Technovation, Vol. 25, No. 1, pp.33-43. 
Simpson, W.G. and Kohers, T. (2002) 'The link between corporate social and financial performance: evidence from the banking industry', Journal of Business Ethics, Vol. 35, No. 2, pp.97-109.

Singh, P.J. and Smith, A.J.R.R. (2004) 'Relationship between TQM and innovation: an empirical study’, Journal of Manufacturing Technology Management, Vol. 15, No. 5, pp.394-401.

Slater, S.F. and Narver, J.C. (1998) 'Customer-led and market-oriented : let's not confuse the two', Strategic Management Journal, January 1997, Vol. 19, pp.1001-1006.

Temri, L., Riviere-Giordano, G. and Kessari, M.E. (2012) 'Innovation et développement durable dans les entreprises agroalimentaires du Languedoc-Roussillon', Ecole d'été 2012 du RRI: Les Nouvelles Dimensions des Systèmes Sectoriels de l'innovation, Montpellier, FRA.

Terziovski, M. and Samson, D. (1999) 'The link between total quality management practice and organisational performance', International Journal of Quality \& Reliability Management, Vol. 16, No. 3, pp.226-237.

Ubius, U. and Alas, R. (2012) 'The impact of corporate social responsibility on the innovation climate', Engineering Economics, Vol. 23, No. 3, pp.310-318.

Ullmann, A.A. (1985) 'Data in search of a theory: a critical examination of the relationships among social performance, social disclosure, and economic performance of US firms', The Academy of Management Review, Vol. 10, No. 3, pp.540-557.

Van Beurden, P. and Gössling, T. (2008) 'The worth of values - a literature review on the relation between corporate social and financial performance', Journal of Business Ethics, Vol. 82, No. 2, pp.407-424.

Vinten, G. (1998) 'Putting ethics into quality', The TQM Magazine, Vol. 10, No. 2, pp.89-94.

Vishwanathan, P. (2010) 'The elusive relationship between corporate social and financial performance:meta-analyzing four decades of misguided evidence', Academy of Management Proceedings, No. 1, pp.1-7.

Waddock, S.a. and Graves, S.B. (1997) 'The corporate social performance-financial performance link', Strategic Management Journal, Vol. 18, No. 4, pp.303-319.

Waworuntu, S.R., Wantah, M.D. and Rusmanto, T. (2014) 'CSR and financial performance analysis: evidence from Top ASEAN listed companies', Procedia - Social and Behavioral Sciences, 164: 493-500.

Wind, J. and Mahajan, V. (1997) 'Editorial: Issues and opportunities in new product development: an introduction to the special issue', Journal of Marketing Research, Vol. 34, No. 1, p.1.

Withanachchi, N., Handa, Y., Karandagoda, K.K.W., Pathirage, P.P., Tennakoon, N.C.K. et al. (2007) 'TQM emphasizing 5-S principles: a breakthrough for chronic managerial constraints at public hospitals in developing countries', International Journal of Public Sector Management, Vol. 20, No. 3, pp.168-177.

Wonglimpiyarat, J. (2010) 'Innovation index and the innovative capacity of nations', Futures, Vol. 42, No. 3, pp.247-253.

$\mathrm{Xu}, \mathrm{Z}$., Lin, J. and Lin, D. (2008) 'Networking and innovation in SMEs: evidence from Guangdong Province, China', Journal of Small Business and Enterprise Development, Vol. 15, No. 4, pp.788-801.

Yam, R.C.M., Guan, J.C., Pun, K.F. and Tang, E.P.Y. (2004) 'An audit of technological innovation capabilities in Chinese firms: some empirical findings in Beijing, China', Research Policy, Vol. 33, No. 8, pp.1123-1140.

Zahra, S.A. and Covin, J.G. (1995) 'Contextual influences on the corporate entrepreneurship-performance relationship: a longitudinal analysis', Journal of Business Venturing, Vol. 10, No. 1, pp.43-58.

Zahra, S.A. and Neubaum, D.O. (1998) 'Environmental adversity and the entrepreneurial activities of new ventures', Journal of Developmental Entrepreneurship, Vol. 3, No. 2, pp.123-140.

Zink, K.J. (2007) 'From total quality management to corporate sustainability based on a stakeholder management', Journal of Management History, Vol. 13, No. 4, pp.394-401. 